り大きな違いは生じない特性を持っているが, 今回の調査で自動現 像機の種類 (処理液のタンク混合式, 直前混合式)により適正な現像 温度に違いがあることが解った。

186 マンモグラフィの画像・線量評価の検討(杤木県内の実態調 査を基に)

栃木県済生会宇都宮病院·診療放射線技術科伊藤愛子，土屋恭子 園部富美恵，中島由希子，青木鮎子

杤木県立がんセンター・放射線技術部 加藤英樹，栗原あゆみ

【目的】乳癌検診においてマンモグラフィの画質は診断精度に最も大 きな影響を与える．画質の向上と精度管理にはどういった因子が関 係しているのかを県内のマンモグラフィ実施施設に対してアンケー トによる実態調査を行い，検討をした。

【万法】1，マンモグラフィの実態調査. 2, 線量測定 : マンモグラ フィ精度管理中央委員会のマニュアルに準じ, 線量測定にはガラス 線量計を使用して行った.3, 画像評価：RMI156ファントムを指定 条件で撮影したフイルムを評価した，評価法はマニュアルに準拠し 判定した。 1 と 2 拈よ゙゙ 1 と 3 の相関関係を検討した。

【結果】精中委による認定技師が撮影を行っている施設は, 平均乳腺 線量には差が見られなかったが，画質評価では，1２点の差が出 た. 他の画質に影響している要因としては, 撮影件数, 品質管理実 施頻度などがあげられた。

【考察】精度管理は画質に影響を与える因子であること分かったが， 精中委の評価法による画質評価では，大きな差にはならなかった。 しかし，日常的品質管理に起因すると思われるアーチファクト(ゴミ やローラー部のキズ)が目立つフイルムが多く見受けられた。ママンモ グラフィが早期がん発見の役割を果たす為には, 画質評価スコア の点数ばかりにとらわれず, 日々の清掃を欠かさず, 精度管理を徹 底して行っていく必要があると考える。

\section{7 マンモグラフィ用増感紙の温度特性に関する検討}

\section{東京都立保健科学大学 川口愛}

群馬県立県民健康科学大学 根岸 徹

首都大学東京 安部真治，加藤 洋

コダック(株) ・ヘルス事業部 石川光雄

【目的】マンモグラフィでは乳房の形態から高画質な画像が求めら れ，常に高い水準の画像を得るための日常の精度管理が重要とされ ている。そこで今回マンモグラフィ用増感紙の蛍光体である $\mathrm{Gd} 2 \mathrm{O} 2 \mathrm{~S}: \mathrm{Tb}$ (酸硫化ガドリニウム・テルビウム)が温度によって発 光強度が異なることに着目し, カセッテ温度とフィルム濃度の関係 について調べ, 増感紙の温度特性が日常の精度管理に及ぼす影響と 被ばく線量低減の可能性について検討を行った。

【方法】Min-R 2000スクリーン/フイルムシステム (kodak社製)を用 い，室温 $20^{\circ} \mathrm{C}$ においてカセッテ温度を $10 \sim 30^{\circ} \mathrm{C}$ 程度に変化させ，管 電圧 $28 \mathrm{kV}$ ，管電流時間積 $32 \mathrm{mAs}$ の同一撮影条件にて ACR 推奨ファン トムを撮影し, カセッテ温度変化とフィルム濃度の関係を検討し た.さらに各社のS/F系についても同様に実験し, 比較検討を行っ た.

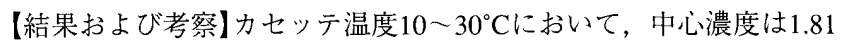
〜 1.40 と変化しカセッテ温度の上昇によりフィルム濃度が低下する 相関性がみられた，各社のS/F系についてもカセッテ温度による濃度 差に違いはあるが同様な相関性が見られた。そこでフィルム・増感 紙それぞれの温度特性について検討したところ,フィルム濃度はほ とんど変動しなかったが, 増感紙は温度の上昇により蛍光量の減少 が見られた。これより増感紙の発光強度が温度によって变化し， フィルム濃度に影響を及ぼしたと考えられ，日常の精度管理におい て増感紙の温度特性がフィルム濃度に及ぼす影響は無視できないと 思われた。さらにカセッテ温度 $10^{\circ} \mathrm{C}$. 管電流時間積 $25 \mathrm{mAs}$ での ACR
推奨ファントム中心濃度は $30^{\circ} \mathrm{C} \cdot 32 \mathrm{mAs}$ とほぼ同等となり，20\%程 度被ばく線量低減の可能性があると思われる。

188 モンテカルロ計算によるサイバーナイフ・ビームの線量評価 熊本大学・医学部保健学科 荒木不次男

熊本放射線外科 田尻新吾, 富永弘史, 古後佳生

【目的】サイバーナイフは $\mathrm{SAD}=80 \mathrm{~cm}$ で定義された $5-60 \mathrm{~mm}$ 径の12種類 の円形コリメー夕を用いたIGRT専用装置である。サイバーナイフは 一般的なりニアックと異なり, 平坦度フィル夕を装備していない。 このため，60mmコリメータでも十分な平坦度が得られず，ファー マ型電離箱では線量を過小評価する。したがって, 実際の測定にお いては微小電離箱より, さらに電離容積の小さい半導体検出器が使 用されることが多い. 本研究では, 半導体検出器によるビームデー 夕を検証する目的で，モンテカル口計算によるサイバーナイフ . ビームの線量評価を行った。

【方法】サイバーナイフ・ヘッドの構造は, EGSnrc/BEAMnrcモンテ カルロコードを用いてシミュレーションを行った。 また，深部量百 分率 (PDD) と軸外線量比 (OAR) はDOSXYZnrc コードを用いて計算し

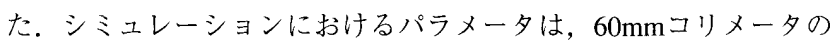
測定PDDとOARに一致するように，入射電子のエネルギーと半径方 向の強度分布を決定した，その後，5-60mmのすべてのコリメータの $\mathrm{PDD}, \mathrm{OAR}$, 出力係数 $(\mathrm{OPF})$ について計算し, 測定值との比較・検 証を行った。

【結果㧍よび考察】モンテカルロ計算の結果は, すべてのコリメータ において半導体検出器によるPDD，OARと良く一致することが検証 できた，OPFの測定值は7.5mm以上のコリメータサイズでモンテカ ルロ計算值と $2 \%$ 以で一致したが, $5 \mathrm{~mm}$ コリメータでは半導体 検出器の值がモンテカルロ計算値より $5 \%$ 高くなった。これは, 半 導体検出器の水不等価性に起因していることがモンテカルロ計算で 明らかになった。

【結論】モンテカルロ計算は, サイバーナイフ・ビームの線量測定の 検証および線量評価に有用であった。

189 肺ファントム中の電離箱壁から発生する 2 次電子が電離電 荷へ与える影響

東京都立保健科学大学・放射線学科 上山忠政、及川奈保子

苅谷有希、藤田幸男，松井さやか

首都大学東京・健康福祉学部 明上山温, 齋藤秀敏

【目的】早期肺がんに対する定位放射線治療では，小さな標的に対し て確実に線量を投与する必要がある。この治療の線量検証と線量訳 算アルゴリズムの精度確認のため，治療計画装置により計算された 線量分布と胸部ファントムでの実測による線量分布を比較し，評価 することが多い，しかし，電離箱壁の密度は肺より大きいが，電離 箱壁からの 2 次電子による影響を考慮した報告は少ない。このため 本報告では，肺ファントム中での電離箱壁の存在が電離電荷に及ぼ す影響を検討したので報告する。

【方法】肺ファントムから発生する 2 次電子数と電離箱壁から発生す る 2 次電子数の比の変化を, EGSモンテカルロシミュレーションに より計数した。シミュレーションでは, 密度 $0.28 \mathrm{~g} \mathrm{~cm}^{-3} の$ Tough Lung (京都科学)の後面に電離箱を配置したモデルを構築し, 壁物質の厚 さを $0.01 \mathrm{~cm}$ 毎に $0.0 \mathrm{~cm}$ から $0.2 \mathrm{~cm}$ まで増加させ, 2 次電子数の変化を 求めた．X線エネルギーは，4，6および10MVを使用した。

【結果】4 MV X線の場合, 電離箱壁からの 2 次電子の割合は, 比較 的壁厚の薄い段階でビルドアップし，プラトーに達した．X線エネ ルギーが高いほど，電離箱壁からの 2 次電子の割合は緩やかに増加 する傾向を示した。

【結論】X線エネルギーの低い場合, 電離箱壁に対する光子の質量減 弱係数が大きいため, 薄い電離箱壁厚の段階から壁からの 2 次電子 